\title{
Managing an elusive force? The Holy Spirit and the anointed articles of Pentecostal prophets in traditional religious Africa
}

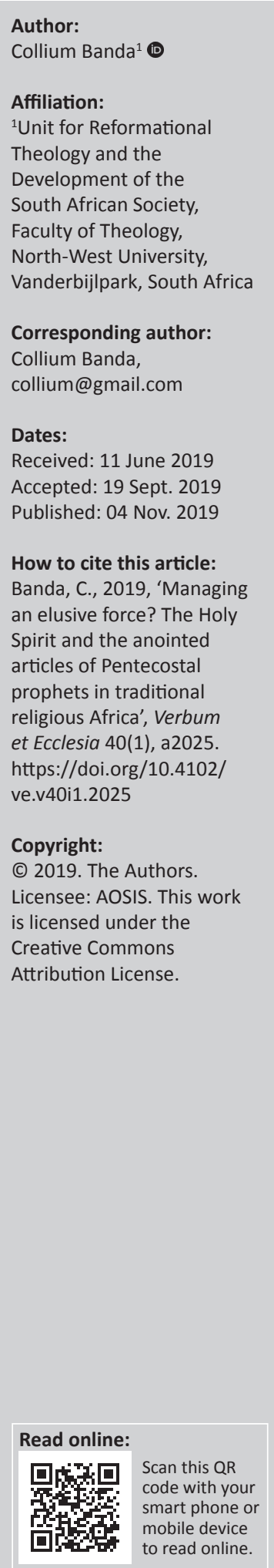

The use of anointed objects among African Pentecostal prophets as instruments of taping the power of the Holy Spirit is analysed from a perspective of the personality and divinity of the Holy Spirit and the use of magical charms in African traditional religions (ATRs). The main question answered in this article is the following: what does the use of anointed objects among African neo-Pentecostal prophets reveal about the underlying understanding of the Holy Spirit? It is argued that the use of anointed objects to tap into the Spirit's power treats the Spirit as an elusive power that is controlled magically. It is further argued that in Africa, the use of anointed objects resonates with the use of magical charms in ATR. The Christian reliance on anointed objects is challenged by looking at some aspects of the divinity and personality of the Holy Spirit. The significant contribution of the article lies in challenging African Pentecostals to relate to the Holy Spirit as a personal divine being instead of an elusive impersonal force that could be mastered only by anointed objects.

Intradisciplinary and/or interdisciplinary implications: This article uses the disciplines of systematic theology, ATRs and biblical theology to analyse the undermining of the personality and divinity of the Holy Spirit among African Pentecostal prophets by their using anointed objects as instruments of conveying the Holy Spirit's presence and power in believer's life and activities.

Keywords: Neo-Pentecostal anointed articles; neo-Pentecostal icons; African Pentecostal prophets; the Holy Spirit in Africa; African magical charms.

\section{Introduction}

The use of various icons to heal people, drive away evil spirits and usher people into a state of blessedness is a strong element in the religious system of African Pentecostal prophets. This article critiques this use of anointed articles by African Pentecostal prophets in light of the divinity and personality of the Holy Spirit and reliance on magical charms in African Traditional Religions (ATRs). African Pentecostal prophets belong to neo-Pentecostalism and are distinct from the holiness movement of classical Pentecostalism which emphasises self-denial based on the otherworldly suspicion of material comforts of this world. On the other hand, neo-Pentecostalism distinguishes itself with an overt craving for supernatural power to attain material prosperity and human flourishing in this present life. Anointed articles, such as oil, water and various items, blessed by the prophets to impart on them the power of the Holy Spirit are an important part of the neo-Pentecostal framework for attaining health and wealth in this present world.

Similarly, ATRs have from time immemorial used various articles infused with spiritual powers to tap into the 'mystical power' (Mbiti 1990:16) to heal, protect people from evil spirits, drive away evil spirits, bring people good luck and success among many other purposes. African Pentecostal prophets condemn ATR's magical and spiritual objects as infused with demonic power and insist that only their anointed objects are truly God-infused and approved. Although the prophets also condemn holy objects of the classical African Independent Churches (AICs), a discussion of AICs beyond odd references falls outside the focus of this article.

The use of various holy objects by African Pentecostal prophets, while condemning objects from ATR spiritual practitioners, raises the following question: What does the use of anointed objects of neo-Pentecostal prophets reveal about the underlying understanding of the Holy Spirit? This question is answered by focusing on the Zimbabwean prophetic scene while drawing from a wide range of scholarship on African Pentecostal prophets. The first section defines the use of 
anointed objects among African Pentecostal prophets. The second section looks at how ATR uses magical powers to master and control the spiritual world to work favourably to one's interests. The third section attempts to unpack the underlying theological understanding of the Holy Spirit that informs such a reliance on anointed objects. The last section highlights some important aspects of the Holy Spirit that challenge the African Christian reliance on anointed objects of the Pentecostal prophets. It is hoped that by critiquing the use of anointed objects from the perspective of divine personality of the Holy Spirit, African Christians would carefully guard against relating to the Spirit as an elusive force or power to be trapped by anointed articles from Pentecostal prophets, and would instead seek to draw power from the Spirit by deepening their personal relationship with him

\section{The anointed objects as instruments of God's active presence}

Anointed objects are important features in African prophetic Pentecostalism. Anointed objects feature prominently among African Pentecostal prophets as instruments of enacting God's blessing, enabling and healing power on the believer or a particular place or situation. The commonly used element in anointing is olive oil (Asamoah-Gyadu 2005:234) which the prophets distribute or sell in tiny bottles to individuals for self-anointing or to place in strategic positions in their homes, business premises or in their personal vehicles to dislodge evil spirits believed to bring curses which hinder people from flourishing in their lives. Other elements used by Pentecostal prophets include water, the prophet's previously worn clothes (Magaya 2016), items branded with the prophet's name such as armbands, car stickers and T-shirts (Chaya 2017). However, media have reported the use of unusual elements such as cucumbers (Chaya 2016), writing pens for exams (Chitumba 2016; Live Monitor 2016) and even anointed condoms (News24 2015). Some Pentecostal prophets in South Africa have been reported in news using unconventional practices such as commanding worshipers to eat grass, snakes, dog meat, drink petrol and also spraying congregants' faces with house pesticides to drive out demons (Daily Sun 2019; Levitt 2018; Masuabi 2016). Such different elements/practices are deemed holy or anointed because the prophet or pastor prays over them to bless and infuse them with the power of the Holy Spirit.

Biri (2012:5-7) highlights several testimonies from the followers of African Pentecostal prophets, recounting their breakthroughs when they used prophet's portrait, touched prophet's jacket, or touched towels and healing clothes prayed for by prophets. However, as reported in the media, in some sad situations some prophets misused their physical bodies as vessels of anointing, resulting in unethical and illegal conduct that has left many prophets and pastors facing various charges of sexual misconduct, including rape. Many desperate 'people trust these bizarre objects and endure the uncomfortable and humiliating touch from the prophets and pastors because they consider them to bear miraculous powers' (Banda 2018:57).

Anointed objects are considered of immense spiritual value among Pentecostals because they are considered to mediate the presence of God which breaks the power of the evil spiritual realm. Many African Christians use anointed articles because of fear of evil spirits and the retributive reaction of ancestral spirits they had abandoned when they embraced Christianity (Magezi \& Magezi 2017a:3-4). ${ }^{1}$ This fear of spiritual powers drives many African Christians into religious syncretism of having 'one foot' in the church and keeping the other in the ATR to find security in both worlds and also not to provoke abandoned ATR spirituals when one converted to Christianity (Maimela 1991:9; Mugabe 1999:240).

Prominent Zimbabwean Pentecostal prophet Magaya (2015a) describes the securing power of anointed objects as follows:

Anointing oil is a physical symbolism of God's healing and deliverance power. It is a point of contact in spiritual warfare and is a symbol of the Holy Spirit. It protects from deadly dangers and traps, and it does the cleansing and purification. It is the anointing of our Lord Jesus Christ and the Holy Spirit which is a powerful tool in spiritual warfare. The anointing oil destroys or breaks the bondage, burden and oppression caused by the devil because the enemy's yoke connects and binds you with sin, poverty, disease and limitation. The anointing oil therefore breaks all the yokes the devil is using to steal the promise God made to us, that of having dominion over earth and being seated in the heavenly places. (n.p.)

In this comprehensive description of anointing oil, Magaya highlights that anointed articles usher believers into a state of blessedness that destroys all hindrances to one's human flourishing. Similarly, Herald's journalists Rupapa and Shumba (2014) quoted prophet Makandiwa, another high profile Pentecostal prophet in Zimbabwe, announcing that anointing oil 'unlocks all the doors of impossibilities in one's life. It will lubricate your lives and things will start moving smoothly'. In other words, anointing destroys all impediments to a person's success and brings blessedness.

Asamoah-Gyadu (2005:234) highlights that in Pentecostalism the purpose of anointing is 'to effect healing, reverse misfortunes, or empower people for successful living, as the case may be'. The anointed objects are prominently associated with physical healing, empowering individuals for ministry and reversing evil, and the attainment of success and prosperity (Asamoah-Gyadu 2005:241). Anointing is also applied on objects such as houses, cars and business premises to restrain evil influences upon them, or remove the presence of evil spirits on haunted houses (Asamoah-Gyadu 2005:245). Therefore, in Pentecostalism, anointing transmits a state of blessedness into a situation viewed as dead and devoid of God's presence. It breathes life into a dead situation. Thus, anointing in neo-Pentecostalism operates from an 'interventionist theology' (Asamoah-Gyadu 2005:236) and is 1.For a detailed understanding of spiritual insecurity among African Christians, see Mbiti (1990:1-5, 227-228) and Magezi and Magezi (2017b). 
therefore applied in any situation that needs supernatural's intervention. Therefore, the use of anointing objects conveys a desire to effectively 'mediate God's presence and power in, healing, deliverance, and protection against the evils of life' (Asamoah-Gyadu 2005:236-237). In the anointing process, Pentecostal prophets function as channels of God's power and blessings to the believers (Gunda \& Machingura 2013:22; Magezi \& Banda 2017:2-3).

Although the Bible records several incidents where objects were used to perform miracles and healings, it does not provide a precedence where holy objects were sold or distributed to believers as instruments of driving away sickness, demons and cleansing ill-luck. Some of the practices of the African Pentecostal prophets could be evaluated from the perspective of the problematic use of relics in Roman Catholicism. $^{2}$ It is debatable whether James' (5:14-16) instruction to the elders to pray for the sick people and anoint them with oil turned oil into a holy article as projected in modern Pentecostalism. Some churches view baptismal water and elements of the Lord's Table as sacraments infused with God's presence and grace and not mere symbolic objects.

\section{The African background of the use of magical charms in the quest for spiritual power}

To appreciate the value attached to the anointed objects of the Pentecostal prophets in Africa, it is important to understand the importance given by traditional Africans to magical charms. African traditional religion is an important spiritual background to many African Christians, and continues to relentlessly shape and influence how they liveout their Christianity as Africans. For instance many African Pentecostals continue to express a fear of witchcraft that is similar to ATR adherents (Biri 2012:3). ${ }^{3}$ A consideration of entrenched reliance on magical charms in ATR may enlighten the common appeal of anointed objects of prophets in Africa.

Magical charms play a significant role in ATR as means of controlling the impersonal power on which ATR is based (Beyers 2010:2). African traditional religion has an impersonalised view of the spiritual realm, even though Mbiti (1990:29) says: 'God is no stranger to African peoples, and in traditional life there are no atheists'. African traditional religions subscribe to a religious cosmology comprising five main categories: God, the supreme creator and sustainer of creation, including humanity, spirits, ancestral spirits of dead people, non-human spirits and other spiritual powers,

2.Although an analysis of the Roman Catholic theology of relics may add valuable insights into this study, it has not been done because Zimbabwean Pentecostal prophets do not have a high regard for Catholicism because of accepting practices prophets do not have a high regard for Catholicism because of accepting practices study is still necessary to determine some Catholic influences that have percolated study is still necessary to deter
into African Pentecostalism.

3.Ironically, it is common to find Pentecostal Christians accusing each other of demon possession and practising Satanism (Biri 2012:5; Bulawayo24 News 2017; Chaya 2015) human beings. who are alive and those yet to be born, nonhuman biological life such as animals and plants and all other inanimate objects such as mountains (Magesa 1997:44; Mbiti 1990:15-16). The two realms, the invisible spiritual sphere and the visible physical world, are intricately interconnected and influence each other, making traditional Africans live within a spiritualised dimension. However, despite ATR's firm belief in God as creator and sustainer of the universe, it is also believed that there is a huge distance between God and humanity that is only closed by the hierarchy of spirits. Thus, ATR is a religion based on an impersonal power, because although God sustains the universe, he is viewed as detached from it and has delegated its direct care to the hierarchy of spiritual mediators, including the family, clan and tribal ancestral spirits. Access to God is through ancestral spirits.

The impersonal power is described by different names; Magesa (1997:50) following Placide Tempels calls it 'forces of life' or 'vital forces', while Turaki (2000:2) highlights names such as mana, life force, vital force, life essence and dynamism, high mysterious powers and mysterium tremendum ('awe inspiring mystery'). Van Rooy (1999:238) calls the mystical power cosmic good, prestige, influence, health and good luck. For any creature to exist and be fruitful, it must ensure that it is sufficiently connected to the force of life in order to draw life from it. In addition to morality, religious rituals and ceremonies, and magical charms function as means of keeping individuals connected to the mystical power in order to derive life from it (Magesa 1997:45). Therefore, the entire life of an African, from pre-birth, during birth, after birth, including all major stages of life such as puberty, work, marriage and death, is shrouded with various types of medicinal powers. Traditional Africans are accompanied by various appropriate magical medicines everywhere they go and in every significant course of action they take. Mbiti (1990) states:

Charms, amulets, medicines drunk or rubbed into the body, articles on the roof or in the fields, cuts, knots, and many other visible and invisible, secret and open precautions, are used in all communities for seriously religious intentions, to secure a feeling of safety, protection and assurance. (p. 196)

The powers of magical charms are deployed to all and at one's possessions and strategic interests such as homesteads, fields and animal enclosures, marriage, children and even one's spot or office at the work place. Traditional Africans believe that it is important to be strengthened with strong medicinal powers called ukutshwama in Ndebele and kuromba in Shona. And these powers must constantly be renewed, revitalised or replaced by more powerful ones. It is common to find traditional Africans with incisions on their bodies in which medicines were deposited, or wearing bangles on their arms, necklaces and various other items that have been infused with magical powers. This means that magical charms in ATR have a soteriological effect, they save and harness one's connection to the vital force, without which existence is thought to be impossible. 
Essentially, traditional Africans employ magical charms and medicinal powers to control spiritual realm to act favourably and benevolently towards them. While importance is given to planning and hard work to acquire wealth and progress in one's endeavours, it is, however, believed that greater success lies in the effectiveness of one's medicinal powers. Traditional Africans believe that enemies can use destructive charms to stifle other people's effective planning and cause projects to fail. Therefore, since evil powers hungrily prowl about with the intention of striking any time, 'a person needs to protect himself [and herself]' and 'must be ready at all times' (Imasogie 1983:55) with his or her 'missile-repellents' (Nyathi 2001:21). In fact, 'anyone who fails to avail himself of protective charms may be likened to an industrial worker who fails to take advantage of the safety precautions provided for his good' (Imasogie 1983:65).

As can be seen from the above discussion, the African reliance on magical powers thrives on the belief that access to mystical power and ultimately to God is limited to those with effective magical charms and efficient ancestors (Van Rooy 1999:238). The strength of one's magical charms determines the extent to which one is able to tap power from the mystical power and protect their hold on it. Furthermore, the strength of one's magical charm is important to outmanoeuvre other people's charms in monopolising the mystical power (Magesa 1997:55). Other evil people use magical charms to exclusively monopolise access to vital forces and keep away other people from accessing it, causing them to fail or die. Therefore, since the mystical power needed by an individual is viewed as limited, it means that a person's power could only be increased at the expense of others by manipulating the divine to withhold or withdraw blessings from other people and transfer them to him or her (Van Rooy 1999:238). Therefore, Africans view loses as meaning that an enemy has drawn away their vital power. Thus, magical charms function as instruments of establishing, affirming, protecting and increasing one's access to mystical power. Furthermore, losses, failures, sicknesses and death warrant traditional Africans to consult spirit mediums to ascertain the causes of or the culprits who have caused the loss. A course of treatment often includes medicines to revive and fortify one's hold on mystical power and to avenge on culprit. This shows that the powers of magical charms diminish after some time and have to be either renewed or replaced by new and stronger one. Therefore, the spiritual world is a 'battleground of spirits and powers that use their mystical powers to influence the course of human life' (Turaki 2000:6). The wide use of charms entails that the African spiritual world is a war zone as magical powers wrestle to outdo each other.

High reliance on magical charms in ATR shows the anthropocentric and utilitarian value of traditional religious worship system. African traditional religion is humancentred and functional because its main purpose is not obedience to the external call of God per se but the enhancement and security of the earthly existence of human beings (Magesa 1997:54; Mbiti 1990:5; Nyathi 2001:9). In this framework, magical charms function as catalysts that cause God to work for humanity.

However, reliance on magical charms leads to a form of practical atheism and a superstitious view of God. Practical atheism can be defined as the 'denial, in practice, that there is a god, or an attitude according to which the question of the existence of God is irrelevant to the meaning of life and the decisions of human existence' (Pelikan 2014:10). A practical atheist believes that God exists but lives as if God does not exist by not directly relying on him for one's immediate existence. Practical atheism in ATR is demonstrated by a higher direct dependence on magical powers than God. This higher direct reliance on magical charms reflects a superstitious view of God, where God is 'sometimes believed to be the Lord of magic, and Himself subject to its influence, His true image is blurred by exaggerated anthropomorphism' (Nyamiti 1997:58). Nyamiti (1997:58) points out that the outcome of this view of God is 'confusion, pessimism, mistrust and a feeling of insecurity'. For, rather than a religion of freedom, the result is a religion of fear marked with a 'continued craving for power, safety, protection and life, that is dictated to by the traditional worldview and it keeps on influencing behavioural patterns' (Bhebhe 2013:52). This background is important towards understanding the influence of anointed objects of Pentecostal prophets in Africa.

\section{Pneumatological problems in the anointed objects of Pentecostal prophets}

If the anointed charms of Pentecostal prophets function as instruments of the Holy Spirit, what problematic beliefs do they portray about the Spirit?

\section{The notion of the Holy Spirit as an impersonal being deployed by icons}

Anointed icons depict the Holy Spirit as an impersonal power carried around in holy objects and deployed in people's lives and affairs through objects. African Pentecostal prophets fail to critique the impersonal notions of God in ATR, and instead affirm them as true. Instead of critiquing the deistic view of God in ATR, they affirm a view of God's transcendent holiness that lacks God's immensity. Instead of reminding believers that they are the temple of the Spirit indwelt with him, African Pentecostal prophets adopt the ATR deistic impersonal view of God and 'baptise it' (Ngong 2010:126) by telling their congregants to stop consulting traditional spirit mediums and practitioners and consult the prophets. While the prophets redefine and redesign the traditional elements, they maintain the ATR worldview. ${ }^{4}$ This further suggests that the power of the Holy Spirit is only available to the believer through the prophets' human agency and intervention. In many respects, the anointed 4.In Biri's (2012:7) analysis, 'People are attracted [to the prophets] because they are
familiar with the symbolism of the icons and seem to understand and interpret them from their traditional Shona [African] perspective'. 
articles of the African Pentecostal prophets reflect the Ndebele notion ukutshwama or the Shona kuromba, the act of acquiring magical powers from a traditional practitioner in order to acquire wealth, mostly at the expense of other people (Biri 2012:8-9). Asamoah-Gyadu (2005:234) points out that some Pentecostal media preachers place olive oil on radios and TV sets during broadcasts to mediate infusion with power through airways. This impersonalises the Spirit into a magical power mastered and distributed by the prophets through their objects. The impersonalisation of God among African Pentecostal prophets can also be seen in their view of the power of the kingdom of God in terms of a powerful force instead of God's personal activity and reign (Banda 2019).

Pentecostalism with its anointed objects projects a view of the Holy Spirit as limited in his sanctifying power. The limiting of the power of God is reflected in prophet Magaya's (2015b) insistence that people need constant anointing: 'Even in church if you were anointed in 2014 it does not mean that you are still anointed in 2015'. This reflects the above-noted African belief that the power of magical charms should be continually renewed by traditional healers. In unison, prophet Makandiwa (2018) states: 'You can be a child of God, born again in the Spirit and have a demon tormenting you in your life'. Makandiwa (2018) further says, although Abraham was a friend of God, he had a demon of barrenness and that the apostle Paul although born again and anointed by God, he had a demon tormenting him in his life. This promotes the constant longing for power similar to that in ATR. In ATR, people periodically fortify their magical charms and spiritual powers. When Pentecostal prophets proclaim that biblical giants could not escape demon possession despite their being chosen by God, it increases the ordinary believers' sense of spiritual vulnerability which leads to their dependence on prophets and their anointed objects.

The problem is that impersonalising the Holy Spirit as a powerful force undermines his divinity and personality and objectifies him, turning him into an object that could be mastered and controlled by prophets. This undermines the Spirit's sovereignty and independence as God. Anointed objects further promote the ATR-idea of the Holy Spirit as unpredictable and therefore needing to be manipulated through anointed objects. Therefore, the impersonalised worldview of God from ATR remains unchanged. Rather than promoting a craving for personal relationship and walk with the Holy Spirit, what emerges is an ATR-based craving for power that is easily quenched by buying anointed objects and wearing anointed clothing items. The impersonalisation of the Holy Spirit is further demonstrated by how some followers of Pentecostal prophets use portraits of the prophets they follow to heal the sick and exorcise demons from congregants (Biri 2012:5). It is argued that Pentecostal prophets distort the Holy Spirit's personality by inserting themselves as the only channels through whom the Spirit could work in people.
Pentecostals sacralise prophets and turn their anointed objects into protective charms in their testimonies of overcoming serious persistent physical or spiritual problems by looking at prophet's portrait or touching it, or wearing regalia bearing the prophet's name (Biri 2012:5). Placing anointed objects in houses, cars, business premises and selfanointing with anointed oil before undertaking major task such as job interviews turns these objects into lucky charms. It is common to hear Zimbabwean Pentecostal Christians who boastfully declare that they are sons or daughters of some popular prophets. Losing or forgetting one's anointed object would throw one into helpless confusion in a way that disregards God's immanence, omnipotence, omnipresence and biblical affirmations that God is the good shepherd who is always actively present in the affairs of his people even when they are not conscious of it. This leads to distorted views of God and hinders believers from developing a personal relationship with God and directly seeking him. In current socio-economic and politically broken Zimbabwe, affinity with the prophets plays an important role for inspiring hope among discouraged believers so that they could face their daily worsening situation. However, it creates a persistent craving for more powerful prophets who could give new power to enable people to overcome the everescalating situation. The growing reliance on anointed objects potentially creates a vacuum for more powerful prophets, and damages the development of direct personal reliance on the Holy Spirit. One may say, it makes believers forget, or overlook or be totally blinded to the fact that they are the temple of the Holy Spirit, and therefore the Spirit of God resides in them. Since the Spirit lives in them, they ought to pray to him, develop a personal walk with him and seek his strength and wisdom in their life situations. Reliance on anointed objects of African Pentecostal prophets undermine God's sovereign power of being the all unlimited and eternally present God.

\section{Promotion of primitivistic views of the Holy Spirit}

Primitivism is used in this article to refer to the pre-modern ideas of predominantly seeing the world as ruled by spirits, which often leads to high levels of superstition. Ngong (2010:1-11) contends that African Pentecostalism projects the work of the Holy Spirit in pre-modern spiritual notions of fighting evil spirits, demons and witchcraft as if the Spirit has no relevance to technological and scientific issues. Ngong criticises scholars of Pentecostalism who celebrate and endorse the growth of neo-Pentecostalism in Africa as relevant to the African spiritualised worldview and a panacea to the sterile rationalistic historical missionary Christianity that has proved to be irrelevant in the highly spiritualised African milieu. Ngong's point is that the African Pentecostal's overemphasis on spirituality affecting all human problems uncritically resuscitates a primitivistic worldview which sees the events of the world as only spiritual in origin. African Pentecostalism promotes many of the things that modern developed nations abandoned in order to develop and attain better quality of life for their citizens. Developed nations do 
not grow their economies by exorcisms of demonic forces and planting anointed objects at strategic places but through rigorous scientific, technological and engineering research, inventions and development.

African Pentecostalism is problematic in that its main aim is not so much the mission of God but the overcoming of spiritual impediments to personal success (Ngong 2010:128). The problem is an overemphasis on self-aggrandisement than on the mission of God. It is primarily focused with fighting spiritual forces of witchcraft and less with development of sustainable scientific and industrial innovations that transform the lives of God's all people and not just individual Christians (Ngong 2010):

While people elsewhere are struggling to develop technologies and political and economic systems that may enhance the wellbeing of their peoples, Africans are encouraged to pray that God will heal them and make their lives better. While Africans spend their time arguing whether people should rely only on God or on scientific medicine for healing, others are developing various forms of scientific cures. In the end, however, Africans are made to depend on people in Asia, Europe, and America, who have evolved helpful technologies that improve their well being. No wonder, the rise of African Pentecostalism (in the last forty years) has coincided with general decline of the continent. (pp. 129-130)

Anointing objects promote a primitivistic view that undermines the creative role of the Holy Spirit in medical, scientific and technological problems (Ngong 2010:129). To some extent, many prophetic and anointing services in African Pentecostal prophetic services resemble forms of primitive witch-hunting ceremonies or appeasement ceremonies as both problems and their solutions are kept to spiritual issues.

\section{Promotion of anthropocentric Christianity based on practical atheism}

Anointed objects of Pentecostal prophets ultimately promote a human-centred Christianity that practices practical atheism. Earlier practical theism was defined as believing in God and yet conducting oneself as if God does not exist (Pelikan 2014:10). From one point of view, it may be said that the anointed objects of prophets 'democratise' access to God's power by providing an interventionist piety that helps ordinary people to cope with the fears and insecurities of this present life (Asamoah-Gyadu 2005:232). Indeed, prophetic Pentecostalism takes seriously all people at their points of need, as it is with their felt needs, such as sickness and poverty, and their fear of evil spirits. In its democratised nature, prophetic Pentecostalism has 'develop[ed] a type of oral liturgy and ministry in which poor people take active part and thus find a new human dignity' (Mangena \& Mhizha 2013:137).

Just as magical charms in ATR promote a firm acknowledgement that God exists while people live as if he does not exist, the same could be seen in African Pentecostalism. When a Pentecostal prophet such as
Makandiwa preaches that heroes of faith such as Abraham and Paul were demon-possessed despite their faithful personal connection with God, it creates parallel structures for spiritual security that ultimately destroys the believer's confidence and reliance in God. If personal walk with God couldn't save Christians from demon possession, it creates a need for other human efforts to cajole God to intervene. In critiquing the role given to magical charms in ATR, Nyamiti (1997) observes the following:

The African ideas of God and our own relationship with Him have been influenced by superstition ... God's unique role among people has been usurped by the medicine man, the spirits, and superstitious objects. Hence recourse to God is rather rare, and in most cases the general attitude is almost 'practical atheism'. (p. 59)

Nyamiti's (1997) harsh criticism of ATR is also true for the African prophetic Pentecostal's use of anointed objects because it reduces direct dependence on God as his place in the life of a believer is taken by anointed objects. Although this criticism may be countered by declaring that Pentecostals do insist on direct faith in God and proclaim that God is the healer and not the anointed object, the high proliferation of prophetic figures and the high migration between prophetic figures as people search for more powerful anointed objects, show that when solutions are not forthcoming and problems worsening, recourse is not to God but to the prophets and their anointed objects. Instead of recourse to God, they change anointed objects or change prophets altogether.

Furthermore, anointed objects lead to a superstitious view of God, where worship of God is turned into appeasement, mastering and manipulating him by reducing him to 'the Lord of magic, and Himself subject to its influence' (Nyamiti 1997:58). Even the demanded faith is a magical faith that emphasises methods of incantation; consequentially when the desired outcomes do not materialise, people blame their insufficient faith, the failure to say right words and failing to operationalise anointed objects into their lives. Connected to the superstitious view of God is the utilitarian use of religion where instead of serving God and his mission 'religion serves as a survival strategy' (Asamoah-Gyadu 2005:237). As already noted from Pentecostal prophets such as Makandiwa and Magaya, anointing is the means of unlocking all the doors of impossibilities in one's life. The Holy Spirit is just reduced to a tool.

\section{Pneumatology that deepens African dissatisfaction with Christ}

Pentecostal prophets' anointed objects lead to a theology of the Holy Spirit that further deepens African dissatisfaction with Jesus Christ in their indigenous context. It is contended that anointed objects are generally based on poor understanding of Jesus Christ and his salvation that fails to enable Africans to realise his sufficiency in their particular context. Since the inception of Christianity in Africa, many indigenous believers have continued to struggle with the question of the sufficiency of Jesus Christ to their peculiar 
African concerns, resulting in the syncretistic practice of keeping one foot in the church and the other in traditional religious practices. The prominence of anointed objects in Africa is a sign that the old Christological problem of Jesus as a foreign white westerner, irrelevant to the African spiritual context controlled by unpredictable ancestral spirits, witchcraft and sorcery, remains alive (Maimela 1991:8-9; Mugabe 1999:240). However, instead of rejecting Christ as useless to their needs, Africans opt to hold on him because of his promise of eternal life in heaven and remain in the church but keep practicing their traditional religions which they find relevant to their concrete life situations (Maimela 1991:9; Mugabe 1999:240). This problem of not finding Christ sufficient to their African needs was one of the causes for the establishment of AIC, which fused Christianity with elements from ATR.

Rather than solving the problem of insufficiency and irrelevance of Christ in the African indigenous context, the anointed objects exacerbate it. In the end African Christians never know the relevance of Christ in their African context because his role is usurped by reliance on anointed objects. It could therefore be argued that whereas mainline missionary Christianity preached a gospel that did not adequately address the African fears (Taylor 1963:16), African Pentecostal prophets apply their anointed objects in a way that does not help Africans to discover the full sufficiency of Christ for their problems.

\section{The Holy Spirit in addressing the Christian reliance on anointed objects of Pentecostal prophets in Africa}

Considering that the anointed objects are often projected as infused with the power of the Holy Spirit, what could be done in pneumatological terms to empower Christians to abandon reliance on anointed objects and directly rely on the Spirit?

\section{Reaffirmation of the divinity of the Holy Spirit}

An important pneumatological step towards addressing the Christian reliance on anointed objects of African Pentecostal prophets includes reaffirmation of the divinity of the Holy Spirit. It is envisaged that when believers realise that the Holy Spirit is a sovereign divine being, they would realise that he is not a mere force to be manipulated for individual self-aggrandisement. Furthermore, a reaffirmation of the divinity of the Spirit is necessary to challenge believers to be directly connected to him and be enveloped in his great power than seek him in objects. Whereas engaging in the various complex debates on the Holy Spirit is beyond the scope of this article, this section highlights the shortcomings within the African Prophetic Pentecostalism. One significant shortcoming is the tendency of prophets to be agents of the Holy Spirit while undermining his divinity and authority. The reaffirmation of the divinity of the Holy Spirit is necessary to remind Pentecostal Christians that instead of placing their confidence in objects they should place it directly in the Spirit, who is fully God in his divine nature. Furthermore, the Christian is to relate to the Spirit as one relating to God, and not some divine powerful force.

The divinity of the Spirit may be obscured by the immaterial and agency terms used in the Bible to express him. The Holy Spirit is presented as an agent of God's activity such as the power at work in creation, the power that equips and empowers people for God's special task (Ex 31:1-3; Jdg 3:10). The biblical words for 'spirit' (ruach in Hebrew, and pneuma in Greek) are onomatopoeic words, 'both their physical formation and their sound conveying a sense of their basic meaning: the expulsion of wind or breath, the idea of air in motion' (Ferguson 1996:16). In its fundamental meaning, Spirit (the breath of life) expresses God's power, energy, life and activity (Ferguson 1996:16). He is described as the Spirit of God (Gn 1:2; Rm 8:9) and the Spirit of Christ (Rm 8:9; Gl 4:6) which may obscure his individual identity by giving the impression that the Spirit is only an agent of the Father and the Son.

However, the Bible also presents the Holy Spirit as having divine attributes such as omniscience (Jn 14:26), omnipresence (Ps 139:7-10), omnipotence (Lk 1:37), eternity (Heb 9:14), the author of God's truth (2 Pt 1:21), among several other divine attributes. Some events and actions attributed to God in the Old Testament are attributed to the Holy Spirit in the New Testament (Is 6:9-10 cf. Ac 28:25-27; Je 31:31-34 cf. Hebrews 10:15-17). The Bible further ascribes to actions of the Spirit that could only be ascribed to God such as creating and giving life (Job 33:4) and being blasphemed (Mt 12: 30 32); the Spirit has a divine name (Ac 5:1-3); the Christian and the church are depicted as temples of the Holy Spirit (1 Cor 3:16 and 6:19) and he is presented in terms that suggest equality with God and the Son (Mt 28:19-20). While these cited biblical examples do not give conclusive evidence on the deity of the Holy Spirit, they highlight the basis upon which orthodox historical Christianity bases its theology of the divinity of the Holy Spirit. A careful consideration of the Scriptures shows that the work of the Holy Spirit is known fully only through Christ's soteriological work that leads a person to a saving relationship with the Father (Jn 16:13-15). The benediction in 2 Corinthians 13:14 highlights that the Spirit is joined fully and equally with the Father and the Son in the outworking of salvation; therefore, any interpretation of 'the grace of the Lord Jesus Christ, the love of God, and the fellowship of the Holy Spirit' that undermines the deity of the Holy Spirit impoverishes the blessings (Ferguson 1996:31). Thus, the Holy Spirit 'is the member of the Trinity whom the Scripture most often represents as being present to do God's work in the world' (Grudem 1994:634). Summing up the Pauline theology of the Holy Spirit, Fee (1996:34) says: 'In Paul's thinking and experience, the Holy Spirit is not some kind of "it", an impersonal force that comes from God. The Spirit is fully personal, indeed, in the language of a later time, "God very God"'. 
The reaffirmation of the deity of the Holy Spirit is important in responding to the Christian reliance on anointed objects because it points desperate believers to the fullness of God, not objects that could be discarded, lost or need to be replaced when a new more powerful prophet comes onto the scene. If Christians as the temple of the Holy Spirit have the indwelling presence of the Triune God in them, they have no need for anointed objects. To have the fullness of God in one's life and yet remain vulnerable to the point of placing one's security on anointed objects has no pneumatological basis. Christians have no need for anointed objects because they are in God's Spirit whose work 'is to manifest the active presence of God' (Grudem 1994:634).

\section{The power of the Holy Spirit as the personal act of God}

A framework of addressing the African Christian attraction to the anointed objects of Pentecostal prophets also needs reaffirmation of the personhood of the Holy Spirit. Reference to the personality of the Holy Spirit has already been noted in Fee's (1996) assertion of the divinity of the Spirit in the above discussion. The emphasis on the person of the Holy Spirit points out the relational nature of the Spirit. Indeed, some references such as the Spirit being 'poured out' (Jl 2: 28), believers being 'washed' (Tt 3: 5) or being 'filled' (Eph 5: 18) and 'drunk' with the Spirit seem to denote an impersonal being. However, there is also a host of references to the Spirit that affirm him as a person. As Fee (1996:27) highlights, in the Bible 'the Spirit is the subject of a large number of verbs that demand a personal agent'. Christ announced the coming of the Spirit as the coming of a counsellor or teacher (Jn 14:26). The person of the Holy Spirit is also seen in Romans where

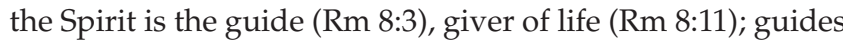
and empowers ( $R m$ 8:11-12); a witness bearer ( $\mathrm{Rm} 8: 15$ ); intercessor for the believers ( $\mathrm{Rm} \mathrm{8:26)}$ and searches hearts and minds (Rm 8:27). In other biblical passages the Spirit is presented as grieved by human sinfulness (Eph 4:30) and works in believers to bear spiritual fruit (Gl 5:22-23). Having looked at various Pauline descriptions of the Spirit in personal terms, Fee (1996:28) says that for Paul the Spirit is not thought of as 'it' but as a 'person'. It is important for Pentecostal Christians to awaken to the person of the Holy Spirit and abandon anointed objects that impersonalise the Spirit of God.

The importance of the person of the Holy Spirit is amplified in the way Grudem (1994:634-653) summarises the distinctive activities of the Holy Spirit into four topics, namely the Holy Spirit empowers, the Holy Spirit purifies, the Holy Spirit reveals and the Holy Spirit unifies. While this also applies to the divinity of the Spirit, it brings out the fact that believers can have a daily personal encounter with the Spirit in their lives. In a religious context ruled by the unpredictability of the impersonal religious power, the divine personality of the Holy Spirit assures the desperate and spiritually vulnerable African Christian, of God's abiding active and securing presence. Furthermore, biblical passages such as Romans 8 that specifically focus on the work of the Holy Spirit in the believer give an assurance of God's predictability by stating that God is not working against us, but for us. Furthermore, the Spirit's divine sovereignty, holiness and faithfulness are assurances that he cannot be manipulated by any person's religiosity and magical charms to work against us.

Grudem (1994) affirms the absolute necessity of an active relational faith with God to tap into the spiritual resources provided by the Spirit. The empowering, the purification, the revelation and the uniting power of the Spirit does not just happen automatically in God's people, they are all determined by the personal faith and obedience of God's believers (Grudem 1994:635). In other words, a poor relationship with God filled with unbelief, disobedience and spiritual laziness limits the Holy Spirit's activities in both individual Christians and the wider Christian community. Anointed objects of Pentecostal prophets promote an impersonalised view of the Spirit by reducing his essence and power to that of an owned magical charm mastered, manipulated and deployed by its owner. Biblical teachings are that Christians relate to the Spirit of God by personally having communal relationship with him. Furthermore, although having a personal relationship with God does indeed include worshipping him by giving money and material gifts, the presence and work of God in the believer are determined not by material gifts as is the case with Pentecostal notion of 'seeding' but by one's faithful obedience to him. As a personal divine being, the Holy Spirit is sovereign, holy, independent, perfect, righteous, just and faithful, and therefore cannot be mastered and manipulated like a magical charm. Acknowledgement of the person of the Holy Spirit is essential to enlighten troubled person to the unconditional love, grace and mercy of God to everyone - reliance on anointed objects overshadows and undermines these important relational attributes of God.

\section{A creative view of the power of the Holy Spirit instead of consumerist view}

The use of anointed objects is further challenged by the creative role of the Holy Spirit which contests the consumeristic view of the Spirit as a power of fighting spiritualised battles with evil forces such as demons and witchcraft that are believed to hinder people's quest for human flourishing (Ngong 2010:128). Ngong's important call is that African Christians need to discard the primitivisation of the Holy Spirit that uncritically only associates the work of the Spirit with fighting evil spiritual powers that hinder access to their good life, as if the Spirit's role is to fulfil their selfish quest to consume good things. Rather than seeing the work of the Holy Spirit as primarily concerned with the elements that dominated primitive pre-civilisation age, there is a need to realise the creative role of the Spirit which could awaken Africans to the sovereignty of God in science, technology, engineering and mathematics (STEM). There is a need to realise that the emergence of scientific rationality has prompted the development of technologies that enhance 
human wellbeing (Ngong 2010:130). Consequently, while some proponents of scientific rationality may reject God, these scientific and technological rationalities are not outside the sovereign reign of God (Ngong 2010:130). The use of anointed objects of Pentecostal prophets promotes primitive superstitions that hinder human agency and human responsibility and promote a consumeristic view of life that stifles people's God-given creative power.

The creative view of the Holy Spirit has in mind the cultural mandate to human beings in Genesis 1:28 to be fruitful and increase, fill the earth, subdue it and rule over all creatures which tasks people to rule the universe creatively and not in a consumeristic manner. Anointed objects from Pentecostal prophets promote consumerism that undermines the role of creation because anointed objects are designed to bring wealth miraculously with less investment on production. Despite its emphasis on health and prosperity, huge and magnificent church buildings and the glamorous and colourful lives of some African Pentecostal prophets, the framework of African prophetic Pentecostalism is technologically and scientifically retrogressive because it is individualistic and consumeristic. The sick, and the poor and troubled are challenged to only seek their own blessings, their own miracles and their own healing. Yet, in a continent faced with poverty, diseases and joblessness, we should also be asking for the Holy Spirit to lead us into developing longlasting technological, medical, engineering and scientific solutions that could lead to long-lasting solutions. There is a need to critique why we only limit the Holy Spirit to miraculous healing of the sick and not in enabling medical researchers find a cure for HIV and AIDS, epilepsy and many other diseases and human conditions that are preached as demons that need miraculous healing. We need to critique why we believe that the Holy Spirit, the creator and the continuous sustainer of the world, has a role only in chasing away demons, destroying acts of sorcery and witchcraft and breaking generational curses, and has no role in industrial, scientific and technological developments that enhance the well-being of all African people. In Africa, the anointed objects of Pentecostal prophets must give way to a Holy Spirit-informed theology of scientific and technological development.

Kakwata (2018) insightfully embraces Grudem's (1994) summary of four distinctive activities of the Holy Spirit, i.e. powering, purifying, revealing and unifying, and calls for the African church to embark on transformational development that is informed and sustained by the Holy Spirit. Rather than conferences to dish out anointed objects to address poverty, disease and suffering in Africa, the conventions should focus on the question of the Holy Spirit in developing scientific, technological, engineering and medical solutions to the continent's problems.This means that the work of the Holy Spirit must not be seen as only confined to a narrow view of the church but in all the places where God has placed his people to be his light and salt, even in their work places and developmental innovations.

\section{Significance of the believer as the temple of the Holy Spirit}

In an article entitled 'Complementing Christ? A soteriological evaluation of the anointed objects of the African Pentecostal prophets', Banda (2018) argues that the anointed objects of African Pentecostal prophets thrive on creating a chasm between God and the Christian and then inserting the prophets and their anointed objects to function as a link between God and the Christian. He argues that the gap is created by projecting believer to be too unholy or too inferior to personally connect with God without the aid of prophets and their holy gadgets. However, this way of promoting reliance on prophets and their anointed objects displays a poor soteriology and pneumatology. Christians do not need the anointed objects of prophets because, soteriologically, salvation places them in close relationship with Christ, which is described by words such as 'being in Christ' and 'Christ in them' (Eph 1:3-14). Furthermore, Christians do not need anointed objects of prophets because, pneumatologically, they are the temple of the Holy Spirit (1 Cor 3:16 and 6:19). They are indwelt in the Holy Spirit and sealed with the Spirit as God's possession (Eph 1:14). Paul points out that to be indwelt with the Holy Spirit is to be indwelt with the Spirit who conquered death by raising Jesus Christ from the dead (Rm 8:11). Furthermore, the indwelling of the Spirit in the believer is the work of the triune God (2 Cor 13:14). Fee (1996:44) highlights this from a Pauline perspective, i.e. one simply cannot be a Christian without the effective work of the Trinity. If the Trinity is at work in the life of a Christian believer, then there is no basis for insisting that African Christians need anointed objects of Pentecostal prophets. Rather, African Christians should realise that God lives in them through the Holy Spirit, and they should deepen their personal walk with him to directly draw from him the spiritual resources needed to live a productive Christian life.

\section{Conclusion}

This article attempted to answer the following question: What does the use of anointed objects of African prophets in the neo-Pentecostal movement reveal about the underlying understanding of the Holy Spirit? In answering this question, the article affirmed that African Pentecostal prophets have a firm understanding of themselves as agents of the Holy Spirit. However, the article argued that the practice of giving anointed objects to believers as a means through which they could experience the healing, enabling and protective powers, is more informed by ATR beliefs than biblical notions of the personality and divinity of the Holy Spirit. Informed by ATR, African Pentecostal prophets seem to present the Holy Spirit as an elusive force or power that needs to be managed through objects. The anointed objects undermine the biblical fact that the Christiana are the temple of the Holy Spirit, which means all born again believers have the Spirit living and working in them. Instead of anointed objects, the Pentecostal prophets should enable their followers to develop a personal relationship and reliance on the Holy Spirit. The Holy Spirit as a personal divine being empowers and enables Christian 
believers by having a personal relationship with them. The greatest challenge for African Pentecostalism is that it must offer African Christians who are desperate for God's securing power something new that is informed by God's personal divine presence instead of the redefined familiar worldview and symbols of ATR. The religion of relating to God as a form of managing an elusive impersonal force must be challenged by a religion of a personal God who is personally engaged and active in the lives and affairs of his people.

\section{Acknowledgements} Competing interests

The author declares that he has no financial or personal relationships which may have inappropriately influenced writing of this article.

\section{Author contributions}

I declare that I am the sole author of this research article.

\section{Ethical considerations}

This article followed all ethical standards for carrying out research without direct contact with human or animal subjects.

\section{Funding information}

This research received no specific grant from any funding agency in the public, commercial, or not-for-profit sectors.

\section{Data availability statement}

Data sharing is not applicable to this article as no new data were created or analysed in this study.

\section{Disclaimer}

The views and opinions expressed in this article are those of the authors and do not necessarily reflect the official policy or position of any affiliated agency of the authors.

\section{References}

Asamoah-Gyadu, J.K., 2005, "'Unction to function": Reinventing the oil of influence in African Pentecostalism', Journal of Pentecostal Theology 13(2), 231-256. https:// doi.org/10.1177/0966736905053249

Banda, C., 2018, 'Complementing Christ? A soteriological evaluation of the anointed objects of the African Pentecostal prophets', Conspectus (Anvil Talks edn.) 2018(2), 55-69.

Banda, C., 2019, 'The impersonalisation of God? A theological analysis of the expression of the power of God's kingdom among Zimbabwean Pentecosta prophets', In die Skriflig 53(1), a2395. https://doi.org/10.4102/ids.v53i1.2395

Beyers, J., 2010, 'What is religion? An African understanding', HTS Teologiese Studies/ Theological Studies 66(1), Art. \#341, 1-8. https://doi.org/10.4102/hts.v66i1.341

Bhebhe, M., 2013, An African culture of multiple religiosity: The perspective of the Church of Christ in Zimbabwe, Lambert Academic, Saarbrucken.

Biri, K., 2012, The silent echoing voice: Aspects of Zimbabwean Pentecostalism and the quest for power, healing and miracles, viewed 03 April 2014, from https://www. uir.unisa.ac.za/handle/10500/6609.

Bulawayo24 News, 2017, Satanism scare at ZAOGA?, viewed 04 June 2019, from https://bulawayo24.com/index-id-news-sc-national-byo-111414.html.

Chaya, V., 2015, Satanism scare hits Harare school, viewed 14 May 2017, from https:// www.dailynews.co.zw/articles/2015/09/29/satanism-scare-hits-harare-school.
Chaya, V., 2016, Magaya cucumbers raise eyebrows, viewed 22 March 2017, from https://www.dailynews.co.zw/articles/2016/11/28/magaya-cucumbersraiseeyebrows.

Chaya, V., 2017, Magaya switches to water, viewed 22 March 2017, from https:// www.dailynews.co.zw/articles/2017/01/30/magaya-switches-to-water.

Chitumba, P., 2016, Miracle pens fake: Dokora, viewed 04 June 2019, from https:// www.chronicle.co.zw/miracle-pens-fake-dokora/.

Daily Sun, 2019, 5 Times pastors went too far!, viewed 04 June 2019, from https:// www.dailysun.co.za/News/National/5-times-pastors-went-too-far-20190226.

Fee, G.D., 1996, Paul, the Spirit, and the people of God, Hendrickson, Peabody, MA.

Ferguson, S.B., 1996, The Holy Spirit, IVP, Downers Grove, IL.

Grudem, W.A., 1994, Systematic theology: An introduction to biblical doctrine, IVP, Leicester.

Gunda, M.R. \& Machingura, F., 2013, 'The “Man of God": Understanding biblical influence on contemporary mega-church prophets in Zimbabwe', in E. Chitando, M.R. Gunda \& J. Kügler (eds.), Prophets, profits and the Bible in Zimbabwe: Festschrift for Aynos Masotcha Moyo, pp. 15-28, University of Bamberg Press, Bamberg.

Imasogie, O., 1983, Guidelines for Christian theology in Africa, ACP, Achimota, Ghana.

Kakwata, F., 2018, 'A pneumatological approach to transformational development: Implication for the church', Stellenbosch Theological Journal 4(1), 199-214. https://doi.org/10.17570/stj.2018.v4n1.a10

Levitt, J., 2018, Snake pastor gives congregants dog 'meat and blood' to 'heal' HIV \& cancer, viewed 04 June 2019, from https://www.timeslive.co.za/news/southafrica/2018-10-15-snake-pastor-gives-congregants-dog-meat-and-blood-to-healhiv--cancer/.

Live Monitor, 2016, Pastor's anointed pens selling like hot cakes, viewed 04 June 2019 from https://www.livemonitor.co.za/pastors-anointed-pens-selling-like-hot-cakes.

Magaya, W., 2015a, Prophet Walter Magaya speaks about the anointing oil, viewed 19 March 2018, from http://magaya.hurukuros.com/2015/10/prophet-waltermagaya-speaks-about.html.

Magaya, W., 2015b, Drop the old donkey's jawbone, viewed 20 October 2018, from https://www.facebook.com/ProphetWMagaya/photos/a.306214782830100/709 969752454599/?type=3.

Magaya, W., 2016, Power of the anointing, viewed 23 March 2018, from https://www. youtube.com/watch?v=PgTfFrD6pGA.

Magesa, L., 1997, African religion: The moral traditions of abundant life, Orbis, Maryknoll, NY.

Magezi, V. \& Banda, C., 2017, 'Competing with Christ? A critical Christological analysis of the reliance on Pentecostal prophets in Zimbabwe', In die Skriflig 51(2), a2273. https://doi.org/10.4102/ids.v51i2.2273

Magezi, V. \& Magezi, C., 2017a, 'Healing and coping with life within challenges of spiritual insecurity: Juxtaposed consideration of Christ's sinlessness and African spiritual insecurity: Juxtaposed consideration of Christ's sinlessness and African
ancestors in pastoral guidance', HTS Teologiese Studies/Theological Studies 73(3), a4333. https://doi.org/10.4102/hts.v73i3.4333

Magezi, V. \& Magezi, C., 2017b, 'A pastoral evaluation and responses to the challenge of spiritual insecurity in African pastoral ministry and Christianity', Verbum et Ecclesia 38(1), a1734. https://doi.org/10.4102/ve.v38i1.1734

Maimela, S.S., 1991, 'Traditional African anthropology and Christian theology', Journa of Theology for Southern Africa 76(4), 4-14.

Makandiwa, E., 2018, Bloodline curses: The voice of the blood, DVD disc B, UFI Ministries, Harare.

Mangena, F. \& Mhizha, S., 2013, 'The rise of white collar prophecy in Zimbabwe: A psycho-ethical statement', in E. Chitando, M.R. Gunda \& J. Kügler (eds.), Prophets, profits and the Bible in Zimbabwe: Festschrift for Aynos Masotcha Moyo, pp. 133152, University of Bamberg Press, Bamberg.

Masuabi, Q., 2016, 'Prophet' of Doom: Pastor claims he can heal people with insecticide, viewed 18 July 2017, from https://www.ewn.co.za/2016/11/21/ pastor-claims-he-can-heal-people-with-doom.

Mbiti, J.S., 1990, African religions \& philosophy, 2nd \& enlarged edn., Heinemann Educational, Gaborone, Botswana.

Mugabe, H.J., 1999, 'Salvation from an African perspective', Evangelical Review of Theology 23(3), 238-247.

News24, 2015, Anointed condoms a no-no in Zimbabwe, viewed 04 June 2019 , https://www.news24.com/Africa/Zimbabwe/anointed-condoms-a-no-no-inzimbabwe-20151205.

Ngong, D.T., 2010, The Holy Spirit and salvation in African Christian theology: Imagining a more hopeful future for Africa, Peter Lang, New York.

Nyamiti, C., 1997, 'The doctrine of God', in J. Parratt (ed.), A reader in African Christian Theology, pp. 57-64, SPCK, London.

Nyathi, P., 2001, Traditional ceremonies of AmaNdebele, Mambo Press, Gweru.

Pelikan, J., 2014, The melody of theology: A philosophical dictionary, Wipf and Stock Publishers, Eugene, OR

Rupapa, T. \& Shumba, D., 2014, Thousands queue for Makandiwa's anointing oil, viewed 22 March 2017, from https://www.herald.co.zw/thousands-queue-formakandiwas-anointing-oil/.

Taylor, J.V., 1963, The primal vision: Christian presence amid African religion, SCM, London.

Turaki, Y. 2000, 'Africa traditional religious system as basis of understanding Christian spiritual warfare', viewed 05 May 2019, from https://www.lausanne.org/Brix.

Van Rooy, J.A., 1999, 'The Christian gospel as a basis for escape from poverty in Africa', In die Skriflig 33(2), 235-254. https://doi.org/10.4102/ids.v33i2.626 